\title{
Review Article \\ Recent Progress of Propolis for Its Biological and Chemical Compositions and Its Botanical Origin
}

\author{
Viviane Cristina Toreti, Helia Harumi Sato, Glaucia Maria Pastore, \\ and Yong Kun Park \\ Department of Food Science, College of Food Engineering, State University of Campinas, Monteiro Lobato Street n.80, \\ P.O. Box 6177, 13083-862 Campinas, SP, Brazil
}

Correspondence should be addressed to Yong Kun Park; ykpark@fea.unicamp.br

Received 25 January 2013; Accepted 12 March 2013

Academic Editor: Ewelina Szliszka

Copyright (C) 2013 Viviane Cristina Toreti et al. This is an open access article distributed under the Creative Commons Attribution License, which permits unrestricted use, distribution, and reproduction in any medium, provided the original work is properly cited.

\begin{abstract}
Propolis is the generic name given to the product obtained from resinous substances, which is gummy and balsamic and which is collected by bees from flowers, buds, and exudates of plants. It is a popular folk medicine possessing a broad spectrum of biological activities. These biological properties are related to its chemical composition and more specifically to the phenolic compounds that vary in their structure and concentration depending on the region of production, availability of sources to collect plant resins, genetic variability of the queen bee, the technique used for production, and the season in which propolis is produced. Many scientific articles are published every year in different international journal, and several groups of researchers have focused their attention on the chemical compounds and biological activity of propolis. This paper presents a review on the publications on propolis and patents of applications and biological constituents of propolis.
\end{abstract}

\section{Introduction}

Propolis is a resinous substance collected by Apis mellifera from various tree buds which they then use to coat hive parts and to seal cracks and crevices in the hive [1]. Propolis has been used as a folk medicine since $300 \mathrm{BC}$ [2]. Recently, numerous biological properties of propolis have been reported including cytotoxic, antiherpes, free radical scavenging, antimicrobial, and anti-HIV activities [3-9]. Because of the wide range of biological activities, propolis has recently been extensively used in food and beverages to improve health and prevent diseases [10-12].

The medical application of propolis preparation has led to an increased interest in its chemical compositions and its botanical origins, because so far mainly polyphenol compounds have been identified in propolis collected by Apis mellifera. The flavonoids, the main polyphenols in propolis, have been found to be quantitatively or qualitatively variable, depending on the environmental plant ecology [13-16].

\section{History of Propolis and the Research on Propolis}

The word "propolis" is derived from the Greek pro (for "in front of" or "at the entrance to") and polis ("community" or "city") and means a substance in defense of the hive. Propolis, or bee glue, is a brownish resinous material collected by worker bees from the leaf buds of numerous tree species like birch, poplar, pine, alder, willow, palm, Baccharis dracunculifolia, and Dalbergia ecastaphyllum $[15,17,18]$. In order to manufacture propolis, bees may also use material actively secreted by plants or exuded from wounds in plants [18].

Propolis has been used by man since early times for various purposes as an antiseptic, antioxidant, antiinflammatory, and an adhesive and to seal cracks; to protect wooden and other surfaces. The bees use propolis to repair combs, to strengthen the thin borders of the comb, and to make the entrance of the hive weathertight or easier to defend. Propolis is also used as an "embalming" substance to cover 


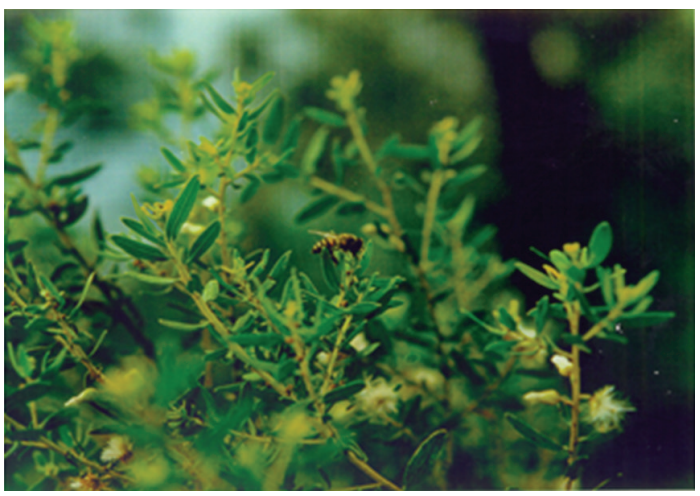

(a)

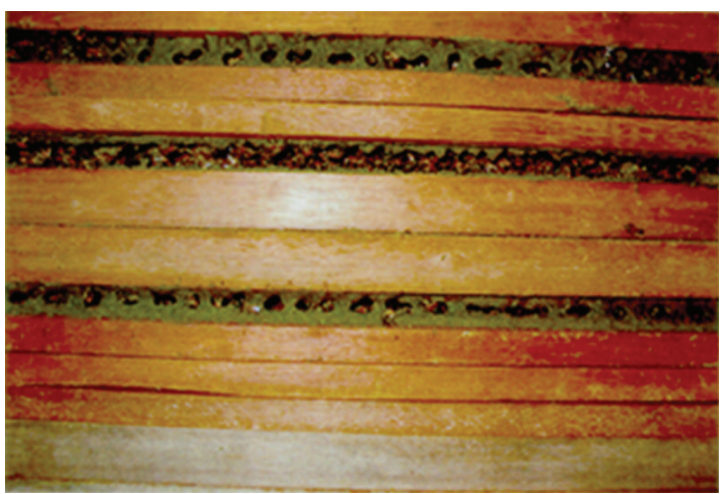

(b)

FIGURE 1: Apis mellifera collecting propolis of Baccharis dracunculifolia to production propolis in Brazil. (a) Apis mellifera collecting leaf apices Baccharis dracunculifolia; (b) deposition of green propolis cracks in the hive.

the carcass of a hive invader which the bees have killed but cannot transport out of the hive. The bees cover the invader with propolis and wax, and the remains are left at the bottom or on one of the walls of the hive $[2,19]$. Figure 1 illustrates the Apis mellifera collecting resinous material from leaf buds of Baccharis dracunculifolia (a) and the deposition of green propolis in the hive (b).

In early records are mentioned substances that cast doubt on the use or not of propolis. In Genesis (c. 1700 BC), tzori was taken to Egypt, once with honey and its healing properties are noted three times in Jeremiah. Twice, tzori came from Gilead, but it was not balm of Gilead which is produced from a tree, Commiphora opobalsamum. Assis believed that "black wax" referred to in the Egyptian Ebers papyrus (c. 1550 BC) may have been propolis. He also considered that Hebrew tzori was an early word for propolis. This occured six times in the Hebrew scriptures and was usually translated as balm or balsam [19].

Egyptians knew very well the antiputrefactive properties of propolis and used it to embalm cadavers. Greek and Roman physicians Aristoteles, Dioscorides, Pliny, and Galen were familiar with the medicinal properties of propolis. It is not known what methods were used for harvesting it in the ancient world, although writers in Greece and Rome were familiar with it. The Greek Historia Animalium referred to a substance mitys, which was probably propolis, as "a cure for bruises and suppurating sores." According to Varro in Rome, propolis was used by physicians in making poultices, and for this reason it brings even a higher price than honey on the Via Sacra [19].

The propolis was employed as an antiseptic and cicatrizant in wound treatment and as a mouth disinfectant, with these uses being perpetuated in the Middle Ages and among Arab physicians. Propolis was also recognized by other peoples unrelated to the Old World civilizations: Incas employed propolis as an antipyretic agent, and the London pharmacopoeias of the seventeenth century listed propolis as an official drug. Between the seventeenth and twentieth centuries, the propolis became very popular in Europe on account of its antibacterial activity [18].
2.1. Publications and Patents. The first work indexed by Chemical Abstracts on propolis was in 1903, and the first patent was described in 1904 (USA-Composition for treating pins and piano strings). One hundred and nine years after the first publication in the Chemical Abstract, the number of publications on propolis reached 3,880 in journal and 2,884 in patents.

Figure 2 shows the number of publications on propolis over the decades; data were obtained by searching the Chemical Abstracts. The global interest in propolis research presents two justifications according to Pereira et al. [20], the first to present diverse biological properties and the second by high added value, the sale price of a bottle in Brazil is about 5 to 10 real.

The scientific production about propolis by document type is the majority about journal and patents as shown in Figure 3.

The processed patent documents contain highly valuable legal, economic, and technical information; hence, the results obtained from their processing make it possible to obtain highly valuable information to reach conclusions useful as key elements for the design of $\mathrm{R} \& \mathrm{D}$, technological surveillance, market studies, and marketing strategies [21].

Since the first patent was filed and until today, it is possible to see that there was a considerable increase in the number of patents in the last thirty years (Figure 4).

According to profile of patents, shown in Figure 5, China, Japan, and Russia are those that hold most of the patents. This fact can be justified by China and Russia being the largest producers of propolis. Today $42 \%$ of patents are Chinese (Figure 5), and the first Chinese patent appeared in 1993 (on "Process for production mouth freshener"). The Japanese have $15 \%$ of patents, and the first appeared in 1988 (about "Deodorants controlling mouth odor"). The first patent was obtained in 1968 on Russian "Toothpaste" and represented $12 \%$ of patents. Brazil deposited its first patent in 1997 on "Dental gel." Some patents are presented in Table 1.

Suárez et al. [21] noted the trend of patent applications according to application area for the period 1972-2000 and observed a high incidence of products with medicinal 
TABLE 1: Relationship of some of the 2,884 international patents (Chemical Abstracts).

\begin{tabular}{lclr}
\hline Year & Country & Title & Register \\
\hline 1904 & USA & "Composition for treating piano pins and strings" & US767499 \\
1920 & Unavailable & "Paint vehicles" & GB146986 \\
1921 & USA & "Waterproof paint" & US1401261 \\
1952 & Unavailable & "Tooth paste and oral disinfectant" & AT172063 \\
1969 & USSR & "A dental elixir" & SU240182 \\
1979 & Romania & "A powder containing soluble propolis" & RO67036 \\
1990 & Japan & "Processed food containing propolis" & JP02154652 \\
1995 & USA & "Treatment of acne/Pharmaceutical compositions for treatment of acne containing & US5399349 \\
2009 & Turkey & "Use of propolis as base material under dental inlays and as filling material for root & TR2009000486 \\
2011 & Turkey & "Extract of propolis and Cramp Bark (Viburnum opulus) with high content of phenolic & TR2011000075 \\
2012 & Korea & compounds useful as natural remedy" & KR2012136769 \\
\hline
\end{tabular}

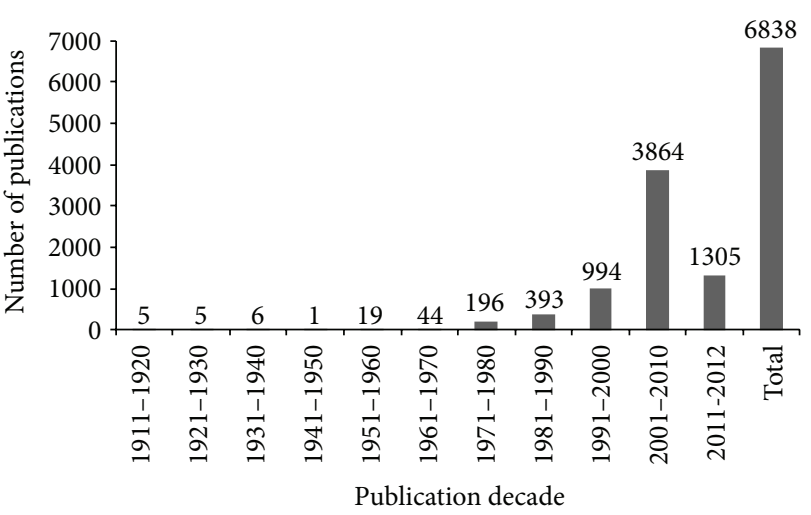

FIGURE 2: Scientific productivity on propolis between the decades (Chemical Abstracts).

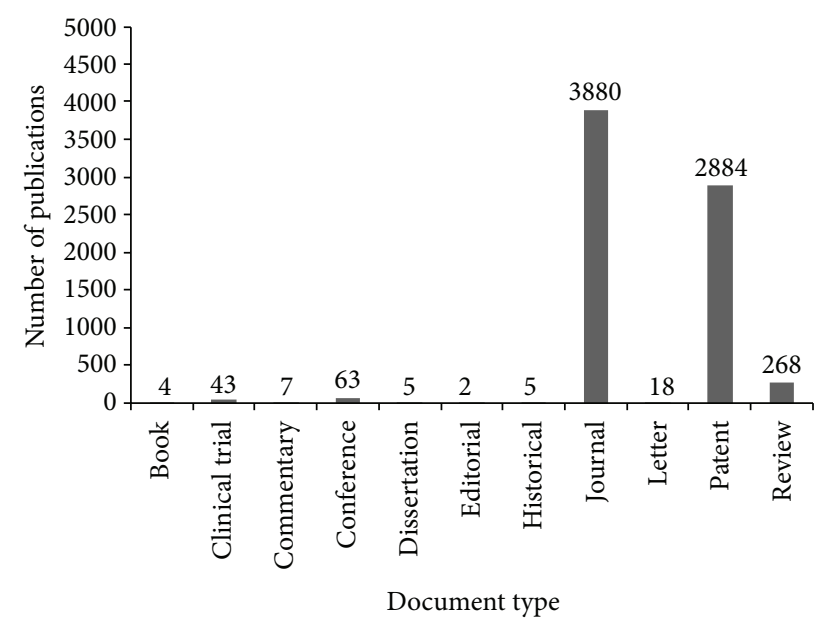

FIGURE 3: Scientific production on propolis by document type (Chemical Abstracts).

and nutraceutical properties and with dermatological applications.

The scientific production on propolis and healthy patents between the decades in shown in Figure 6.

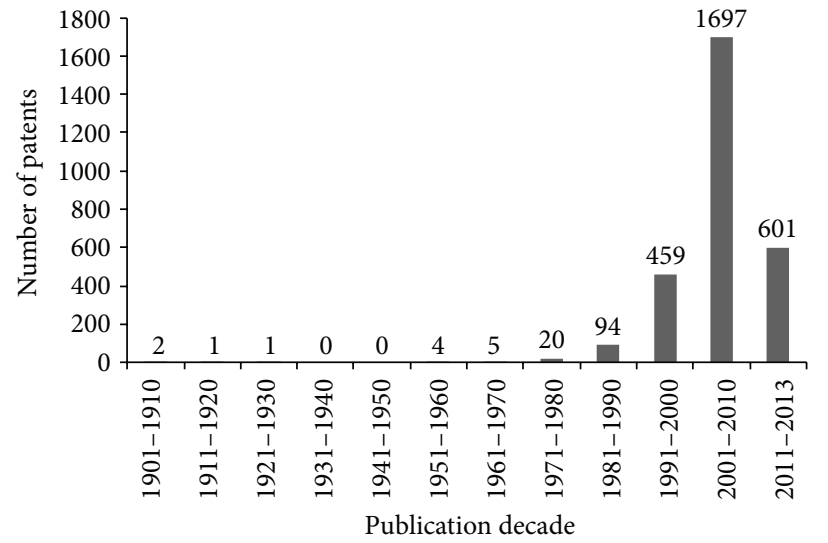

FIGURE 4: Scientific production on propolis by patents (Chemical Abstracts).

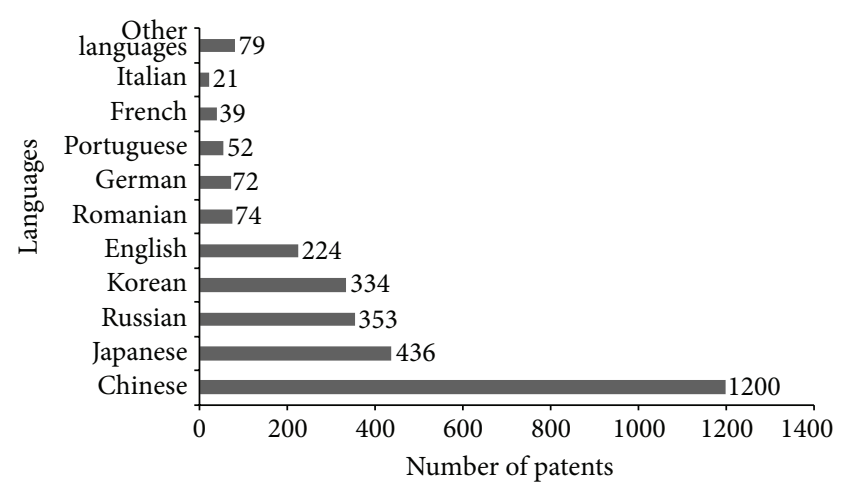

FIGURE 5: Scientific production on propolis by patents and languages (Chemical Abstracts).

The inventions processed according to their priority country are which shown in Figure 7 in which the highest number of filings corresponds to China (476), followed by Japan (177), Korea and Russian with 77, and 29 and filings, respectively. Japan imports almost all the propolis used in the country: $80 \%$ comes from Brazil and 10\% from China 


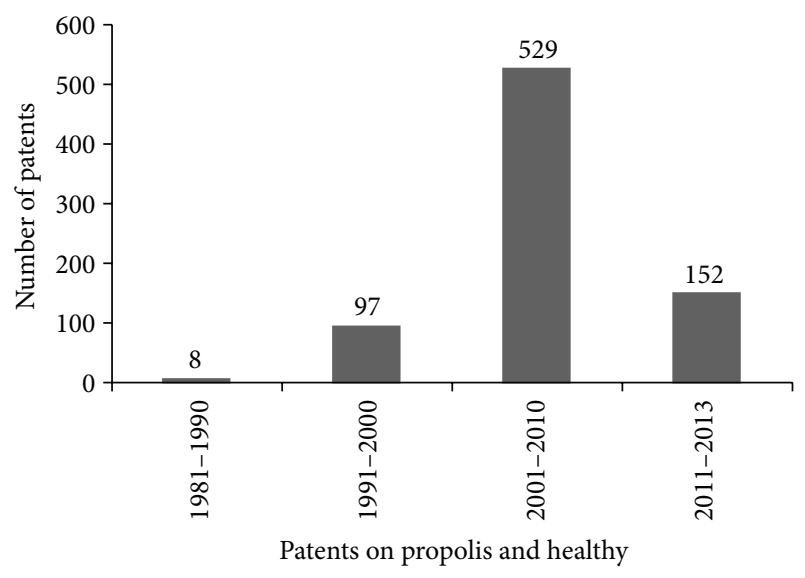

FIGURE 6: Scientific production on propolis and healthy by patents between the decades (Chemical Abstracts).

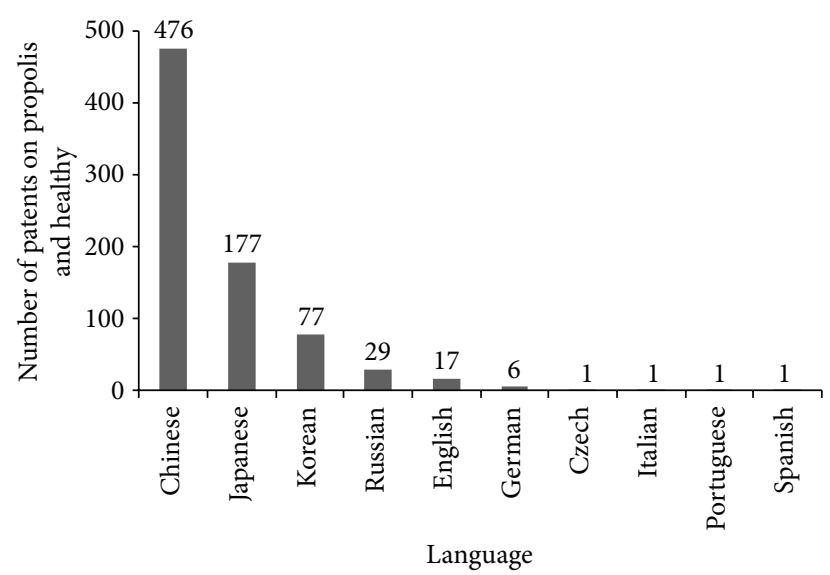

FIGURE 7: Scientific production on propolis and healthy by patents and languages (Chemical Abstracts).

TABLE 2: Brazilian propolis export market [49].

\begin{tabular}{cccc}
\hline Year & $\begin{array}{c}\text { Quantity export } \\
(\mathrm{Kg})\end{array}$ & $\begin{array}{c}\text { Value } \\
(\mathrm{U} \$ \mathrm{~S})\end{array}$ & $\begin{array}{c}\text { Value per kilo } \\
(\mathrm{U} \$ S / \mathrm{Kg})\end{array}$ \\
\hline 2010 & 51,213 & $4,346,604$ & 84.87 \\
2011 & 38,845 & $4,537,727$ & 116.81 \\
2012 & 41,721 & $5,401,643$ & 129.47 \\
\hline
\end{tabular}

and other countries, and this is shown in their inventions, since in the analysis carried out to the content of the Japanese inventions we can see that the Brazilian propolis is the target of invention [21].

Six percent of patents filed by 2012, refers to the use of propolis for dental treatment (Figure 8). According to Pereira et al. [20], this is one of the most widely studied applications of propolis worldwide.

According to the Ministry of Development Industry and Foreign Trade of Brazil [22], the Brazilian export market of propolis in the year of 2012 was $41,721 \mathrm{Kg}$ corresponding about \$5,401,643. These values can be observed in Table 2 .

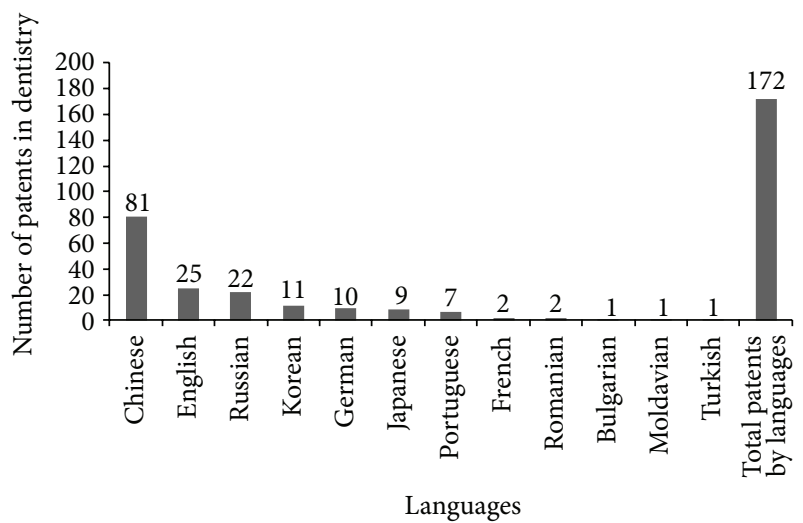

FIGURE 8: Scientific production on propolis for dental treatment by patents and languages (Chemical Abstracts).

Analyzing the data, it is possible to observe that there was a drop in sales in 2011 compared to 2010. Regarding the value of the product, there was an increase of over 50\% in 2012 compared to 2010. According to Aga et al. [23], the country that buys Brazilian propolis is Japan, and its extensive use in foods and beverages intended to maintain or improve human health.

\section{Chemical Composition and Propolis Activity}

3.1. Chemical Composition. Propolis is a complex resinous mixture which contains approximately $50 \%$ of resin and balsam, $30 \%$ of wax, $10 \%$ of essential and aromatic oils, $5 \%$ of pollen, and $5 \%$ of impurities [24]. The chemical composition of propolis is highly variable mainly due to the variability of plant species growing around the hive, from which the bees collect the exudates [18, 25-28]. Additionally, propolis composition can vary depending on the seasonality, illumination, altitude, collector type, and food availability and activity developed during propolis exploitation [29-33].

Much work has been conducted on the chemical composition and biological activities. Until now, more than 300 chemical constituents have been identified in propolis from different regions [34]. The main chemical classes present in propolis are flavonoids, phenolics, and aromatic compounds (Figure 9) [35, 36]. Propolis also contains some volatile oils, terpenes, and bee wax, but these compounds are not believed to contribute as significantly to the chemical properties and effects of propolis [36].

Many analytical methods have been used for separation and identification of propolis constituents. Differents compounds have been identified in ethanol extracts of propolis (Table 3).

3.2. Method of Extraction. The method of extraction and solvent can change the chemical composition of propolis extract. Commercial products such as tablets, capsules, ampoules, and syrups are prepared with ethanolic extract of propolis. Methanol is only used for research purposes. Some varieties 
TABLE 3: Identified compounds in ethanol extracts of propolis.

\begin{tabular}{|c|c|c|}
\hline Sample & Compounds identified & Reference \\
\hline Bulgarian propolis & 3,7-Dihydroxy-5-methoxyflavanone 2,5-dihydroxy-7-methoxyflavanone & {$[50]$} \\
\hline $\begin{array}{l}\text { North and South } \\
\text { Bulgaria }\end{array}$ & $\begin{array}{l}\text { Dihydrocaffeic acid } \\
\text { Dihydroferulic acid } \\
\text { Dihydroxyacetophenone hydroxymethoxyacetophenone } \\
\beta \text {-Phenethyl alcohol } \\
\text { Benzyl alcohol pinobanksin } \\
\text { Pinostrobin } \\
\text { Dimethyl kaempferol }\end{array}$ & [51] \\
\hline Brazil/São Paulo state & 3-Prenyl-4-dihydrocinnamoloxynnamic acid & [23] \\
\hline $\begin{array}{l}\text { Brazil/São Paulo } \\
\text { state/Botucatu city }\end{array}$ & 9-E and 9-Z 2,2-Dimethyl-6-carboxyethenyl-8-prenyl-2H-benzopyran & {$[52]$} \\
\hline Brazil/São Paulo state & $\begin{array}{l}\text { Dehydroabietic acid } \\
\text { Abietic acid } \\
\beta \text {-Amyrine } \\
\text { Triterpenic alcohol of amyrine } \\
\text { Lanosterol isomer with } 9(11) \text { double bond }\end{array}$ & [53] \\
\hline Not reported & $\begin{array}{l}\text { (E)-2,3-Dihydroconiferyl p-coumarate } \\
\text { (E)-3-2,3-Dihydro-2-[2-[(E)-pcoumaroyloxy]-1-methylethyl]-5-benzofuranyl-2- } \\
\text { propenoic acid } \\
\text { (E)-4-(2,3-Dihydrocinnamoyloxy) cinnamic acid } \\
\text { (E)-3-(2,2-Dimethyl-3,4-dihydro-3-hydroxy-2H-1-benzopyran-6-yl)-2-propenoic acid } \\
\text { (E)-3-[2,3-Dihydro-2-(1-methylethenyl)-5-benzofuranyl]-2-propenoic acid } \\
\text { (E)-3-[2,3-Dihydro-2-(1-methylethenyl)-7-prenyl-5-benzofuranyl]-2-propenoic acid } \\
\text { (E)-3-3-[(E)-4-(2,3-Dihydrocinnamoyloxy)-3-methyl-2-butenyl]-4-hydroxy-5- } \\
\text { prenylphenyl-2-propenoic acid } \\
\text { Dihydrokaempferol (aromadendrin) } \\
\text { 6-Methoxykaempferol } \\
\text { 4-Hydroxy-3-prenylbenzoic acid } \\
\text { Plicatin B } \\
\text { Capillartemisin A }\end{array}$ & [54] \\
\hline Japan/Okinawa & Prokinawan & {$[55]$} \\
\hline Brazilian propolis type 6 & Hyperibone A & {$[56]$} \\
\hline Mexico/Champoton & $\begin{array}{l}\text { 1-(3', } 4^{\prime} \text {-Dihydroxy-2' }- \text {-methoxyphenyl)-3-(phenyl)propane } \\
\text { (z)-1-(2'-Methoxy- } 4^{\prime}, 5^{\prime} \text {-dihydroxyphenyl)-2-(3-phenyl)propene } \\
\text { 3-Hydroxy-5,6-dimethoxyflavan } \\
\text { (-)-7-Hidroxyflavanone } \\
\text { (-)-Mucronulatol } \\
\text { (-)-Arizonicanol a } \\
\text { (+)-Vestitol } \\
\text { (-)-Melilotocarpan a } \\
\text { (-)-Melilotocarpan d } \\
\text { (+)-Pinocembrin }\end{array}$ & [57] \\
\hline Greece (six regions) & $\begin{array}{l}\text { 18-Hydroxyabieta-8, 11,13-triene } \\
\text { Dihydroxyabieta-8,11,13-triene; hydroxydehydroabietic acid } \\
\text { 18-Succinyloxyabietadiene } \\
\text { 18-Succinyloxyabietadiene (isomer) } \\
\text { 18-Succinyloxyhydroxyabietatriene }\end{array}$ & [58] \\
\hline Kenyan propolis & $\begin{array}{l}\text { Tetrahydrojusticidin B } \\
\text { 6-Methoxydiphyllin } \\
\text { Phyllamyricin C } \\
\text { Macarangin } \\
\text { Schweinfurthin A } \\
\text { Schweinfurthin B }\end{array}$ & [59] \\
\hline
\end{tabular}


TABLE 3: Continued.

\begin{tabular}{|c|c|c|}
\hline Sample & Compounds identified & Reference \\
\hline $\begin{array}{l}\text { Indonesia/East Java } \\
\text { province/Batu city }\end{array}$ & $\begin{array}{l}\text { 5-Pentadecylresorcinol } \\
\text { 5-(8 } z, 11^{\prime} z \text { Heptadecadienyl)-resorcional } \\
\text { 5-(11'z-Heptadecenyl)-resorcinol } \\
\text { 5-Heptadecylresorcional } \\
\text { Propolin d } \\
\text { Propolin c } \\
\text { Propolin } \mathrm{f} \\
\text { Propolin g }\end{array}$ & {$[60]$} \\
\hline Jordanian propolis & $24(\mathrm{z})-1 \beta-3 \beta$-Dihydroxyeupha-7,24-dien-26-oic acid & {$[61]$} \\
\hline Honduras & $(\mathrm{E}, \mathrm{Z})$-Cinnamyl cinnamate & {$[62]$} \\
\hline Solomon island & Solophenol (A) & {$[63]$} \\
\hline
\end{tabular}

TABLE 4: Propolis of different geographic regions and their principal plants' sources of chemical compounds (from Bankova, 2005).

\begin{tabular}{|c|c|c|}
\hline Geographic origin & Plant source & References \\
\hline Bulgaria & Populus nigra, P. italic & {$[16,50,63]$} \\
\hline Albania & Populus nigra & [63] \\
\hline Bulgaria & Populus tremula & {$[16]$} \\
\hline Mongolia & Populus suaveolens & {$[16,63]$} \\
\hline USA (mainland) & Populus fremontii & {$[16]$} \\
\hline USA (Hawaiian islands) & Plumeria acuminate, Plumeria acutifolia & [16] \\
\hline United Kingdom & Populus euramericana & [16] \\
\hline Hungary & Betula, Populus, Pinus, Prunus, and Acacia spp.; Aesculus hypocastane & [16] \\
\hline Poland & Betula, Alnus spp. & [16] \\
\hline Equatorial regions & Delchampia spp. & {$[16]$} \\
\hline Equatorial regions & Clusia spp. & {$[16,64]$} \\
\hline Australia & Xanthorrhoea & {$[2]$} \\
\hline North temperate zone & Poplar, birch, elm, alder, beech, conifer, and horse chestnut & {$[2]$} \\
\hline $\begin{array}{l}\text { Europe, North America, nontropic regions of } \\
\text { Asia (poplar propolis) }\end{array}$ & Populus spp. of section Aigeiros, most often P. nigra L. & {$[1,34,65]$} \\
\hline Russia (birch propolis) & Betula verrucosa Ehrh. & {$[66]$} \\
\hline Brazil (green-alecrim-propolis) & Baccharis spp. Predominantly B. dracunculifolia DC. & {$[14,67]$} \\
\hline \multirow{2}{*}{ Cuba, Venezuela } & Clusia minor & \multirow{2}{*}[16,68-70]{} \\
\hline & Clusia spp. & \\
\hline South Brazil (type 3), Argentine, and Uruguay & Populus alba & [71] \\
\hline Brazil (type 6 from northeastern Brazil) & Hyptis divaricate & {$[14]$} \\
\hline Brazil (type 13 from northeastern Brazil) & Dalbergia ecastaphyllum & {$[17,42]$} \\
\hline
\end{tabular}

of propolis have solubility in water, thereby extracting water should also be considered for study [35].

3.3. Origin Botanical. The materials available to bees for production of propolis are substances actively secreted by plants as well as substances exuded from wounds in plants: lipophilic materials on leaves and leaf buds, resins, mucilages, gums, lattices, and so forth [37].

The composition of the plant source determines the chemical composition of bee glue, and it is dependent on its geographical location; as a result, its biological activity is closely related to the vegetation native to the site of collection $[14,38,39]$.
Bankova [38] discusses the diversity of the chemical composition of propolis and the problem of standardization. The issue is based on the chemical composition of propolis which varies with the plant source collection. Dealing with reliable criteria for chemical standardization of different propolis types is needed, but such generally accepted criteria do not yet exist. There is still a lot of work to be done to achieve standardization of other propolis types. Working with standardization material will allow scientists to connect a particular chemical propolis type to a specific type of biological activity and formulate recommendations. Table 4 illustrates propolis of different geographic regions and their principal plant sources of chemical compounds. 
TABLE 5: Classification of Brazilian propolis, according to their physicochemical characteristics and location [17, 41].

\begin{tabular}{lcc}
\hline Groups & Color & Ethanolic extract of propolis \\
\hline Group 1 (RS5) & Yellow & Origin of propolis \\
Group 2 (RS1) & Brown & Southern \\
Group 3 (PR7) & Dark brown & Southern \\
Group 4 (PR8) & Brown & Southern \\
Group 5 (PR9) & Greenish brown & Southern \\
Group 6 (BA11) & Reddish brown & Southern \\
Group 7 (BA51) & Greenish brown & Northeast \\
Group 8 (PE5) & Dark brown & Northeast \\
Group 9 (PE3) & Yellow & Northeast \\
Group 10 (CE3) & Dark yellow & Northeast \\
Group 11 (PI1) & Yellow & Northeast \\
Group 12 (SP12) & Green or greenish brown & Northeast \\
Group 13 (AL) & Red & Southeast \\
\hline
\end{tabular}<smiles>O=c1c(O)c(-c2ccccc2)oc2cc(O)c(O)cc12</smiles>

Kaempferol<smiles>O=C1c2c(O)cc(O)cc2OC(c2ccccc2)C1O</smiles>

Galangin<smiles>O=C1CC(c2ccccc2)Oc2cc(O)cc(O)c21</smiles>

Pinocembrine<smiles>CC(C)=CCc1cc(/C=C/C=O)cc(CC=C(C)C)c1O</smiles>

3,5 Diprenyl- $\rho$-coumaric (artepellin C)<smiles>O=c1c(O)c(-c2ccc(O)c(O)c2)oc2cc(O)cc(O)c12</smiles>

Quercetin<smiles>O=c1cc(-c2ccccc2)oc2cc(O)cc(O)c12</smiles>

Chrysin<smiles>O=C(O)C=Cc1ccc(O)cc1</smiles>

$\rho$-Coumaric acid<smiles>CC(=O)/C=C/c1ccc(OC(=O)CCc2ccccc2)c(CC=C(C)C)c1</smiles>

Saccharin

FIGURE 9: Some typical flavonoids and phenolics present in green propolis. 
TABLE 6: Chemical constituents of propolis that possess known pharmacological activities.

\begin{tabular}{|c|c|c|}
\hline Chemical compounds & Activities & References \\
\hline Acacetin & Anti-inflammatory & {$[72]$} \\
\hline Apigenin & Anti-inflammatory & {$[72]$} \\
\hline Artepillin C & $\begin{array}{l}\text { Antimicrobial } \\
\text { Antitumor activity } \\
\text { Antioxidative }\end{array}$ & {$[23,41,73-75]$} \\
\hline Caffeic acid phenethyl ester & $\begin{array}{l}\text { Antitumor activity } \\
\text { Anti-inflammatory }\end{array}$ & {$[76,77]$} \\
\hline Chrysin & Anti-inflammatory & {$[72]$} \\
\hline Caffeic acid & $\begin{array}{l}\text { Antibacterial } \\
\text { Antifungal } \\
\text { Antiviral } \\
\text { Anti-inflammatory }\end{array}$ & {$[72,78-80]$} \\
\hline Cinnamic acid & Anti-inflammatory & {$[72]$} \\
\hline Dicaffeoylquinic acid derivatives & Hepatoprotective & {$[81]$} \\
\hline Ferulic acid & Anti-inflammatory & {$[72]$} \\
\hline Galangin & Anti-inflammatory & {$[72]$} \\
\hline Gallic acid & Anti-inflammatory & {$[72]$} \\
\hline Moronic acid & Anti-HIV & {$[9]$} \\
\hline Isoferulic acid & Anti-inflammatory & {$[72]$} \\
\hline Pinostrobin & Local anesthesia & {$[82]$} \\
\hline Protocatechuic acid & Anti-inflammatory & {$[72]$} \\
\hline Pinocembrin & $\begin{array}{l}\text { Antibacterial } \\
\text { Antifungal } \\
\text { Antimold } \\
\text { Local anesthesia }\end{array}$ & {$[79,80,82,83]$} \\
\hline Propofol & Antioxidative & [7] \\
\hline$\rho$-Coumaric acid & Antibacterial & {$[74]$} \\
\hline$m$-Coumaric acid & Anti-inflammatory & {$[72]$} \\
\hline$o$-Coumaric acid & Anti-inflammatory & {$[72]$} \\
\hline Quercetin & $\begin{array}{l}\text { Anti-inflammatory } \\
\text { Antiviral } \\
\text { Antihistamine } \\
\text { Ulcer healing } \\
\text { Capillary strengthening }\end{array}$ & {$[41,78]$} \\
\hline $\begin{array}{l}\text { Volatile constituents } \\
\text { (phenols, esters, terpenoids, etc.) }\end{array}$ & Antibacterial & {$[64]$} \\
\hline 2,2-Dimethyl-6-carboxyethyl-2H-1-benzopyran & Antimicrobial & {$[81]$} \\
\hline 3-[3,4-Dihydroxy-5-prenylphenyl]-2-(E)-propenoic acid & Antioxidative & {$[84]$} \\
\hline
\end{tabular}

3.4. Classification of Brazilian Propolis. It was found that propolis from several regions of Brazil show different chemical composition, depending on the local flora at the site of collection [40]. The propolis from Brazil was classified in types according to its geographical origin, chemical composition, and source plant as shown in Table $5[17,41,42]$. More studies should be done in order to standardize propolis.

3.5. Activity of Propolis. It is important to note that most of the latest investigations on new propolis constituents are connected to their biological activity. This information is summarized in Table 6. Some compounds from propolis have antibacterial activity, antitumor activity, and antiinflammatory activity, antioxidative and hepatoprotective action.
According to Bankova et al. [34], relating the chemical constituents of propolis with biological activity enables the standardization of the application of propolis. Kumazawa et. al. [28] report that differences in the chemical composition of propolis from different sources change the spectrum of biological activity of propolis.

Some studies have been conducted correlating chemical composition and biological activity, but no tested compounds were isolated [43-47].

\section{Application in Medicine and Dentistry}

Propolis has been found to have a wide spectrum of biological and pharmaceutical properties and has been demonstrated 
TABLE 7: Recent studies on application of propolis in medicine.

\begin{tabular}{|c|c|c|c|}
\hline \multicolumn{4}{|c|}{ Application in medicine } \\
\hline Geographic origin of propolis & Activity attributed & Test performed & References \\
\hline Brazil (southern) & Anti-HIV activity & In vitro (H9 Lymphocytes) & [9] \\
\hline Brazil & Anticancer activity & In vivo-mice (pulmonary tumors) & {$[85]$} \\
\hline Brazil & Anticancer activity & In vitro (human tumor cell lines) & {$[86]$} \\
\hline Brazil (group 3 and group 12) & Suppression of dioxin & In vitro & {$[87]$} \\
\hline Chile & Antioxidant and anticancer & $\begin{array}{l}\text { In vitro } \\
\text { (KB cells-human mouth epidermoid } \\
\text { carcinoma cells; } \\
\text { Caco-2 cells-human colon } \\
\text { adenocarcinoma cells) }\end{array}$ & {$[88]$} \\
\hline Brazil & Anticancer activity & In vitro and in vivo (retinal damage) & {$[89]$} \\
\hline $\begin{array}{l}\text { Brazil (group 3, group 12, and bud resins of } \\
\text { botanical origin) }\end{array}$ & Anticancer activity & In vitro (human prostate epithelial cells) & {$[90]$} \\
\hline Brazil & Antiinfluenza virus activity & In vivo-mice (influenza virus) & {$[91]$} \\
\hline Jordanian & Antibacterial & In vitro & {$[92]$} \\
\hline Tunisia & Anticancer activity & $\begin{array}{l}\text { In vitro (cancer cell lines-HT29, A549, } \\
\text { Hep-2, raw264.7, and Vero) }\end{array}$ & {$[93]$} \\
\hline Brazil (group 12 and artepellin C) & Immunosuppressant & In vitro (CD4 T cell) & {$[94]$} \\
\hline Portugal & Anticancer activity & In vitro (human renal cancer) & {$[95]$} \\
\hline Israel (Kibbutz Yad Mordecai and CAPE) & Anticancer activity & In vitro (human T-cell lines) & {$[96]$} \\
\hline Brazil & Anticancer activity & In vitro (human breast cancer MCF-7 cells) & [97] \\
\hline Brazil (group 12 and group 13) & Anticancer activity & In vitro (human cell lins of leukemia) & {$[98]$} \\
\hline CAPE (derived from honeybee hive propolis) & Anticancer activity & In vitro (human prostate cancer cells) & [99] \\
\hline Brazil & Anticancer activity & In vivo-mice (skin carcinogenesis) & {$[100]$} \\
\hline Poland & Anticancer activity & In vitro (U87MG human glioblastoma) & {$[101]$} \\
\hline
\end{tabular}

TABLE 8: Recent studies on application of propolis in dentistry.

\begin{tabular}{|c|c|c|c|}
\hline \multicolumn{4}{|c|}{ Application in dentistry } \\
\hline Geographic origin of propolis & Activity attributed & Test performed & References \\
\hline Japan & Inhibited glucosyltransferase activity & In vivo-rats & [102] \\
\hline $\begin{array}{l}\text { Brazil (extracts of propolis from the states of } \\
\text { Minas Gerais, São Paulo, Goiás, Mato Grosso } \\
\text { do Sul, Paraná, and Rio Grande do Sul) }\end{array}$ & Inhibited glucosyltransferase activity & In vitro & {$[8]$} \\
\hline $\begin{array}{l}\text { Brazil (extracts of propolis from the states of } \\
\text { Minas Gerais and Rio Grande do Sul) }\end{array}$ & Cariostatic effect & In vivo-rats & [103] \\
\hline $\begin{array}{l}\text { Brazil (extracts of propolis from the states of } \\
\text { Minas Gerais and Rio Grande do Sul) }\end{array}$ & Inhibited glucosyltransferase activity & In vitro & {$[104]$} \\
\hline Brazil (Minas Gerais state) & $\begin{array}{l}\text { Antibacterial activity } \\
\text { Inhibition of cell adherence } \\
\text { Inhibition of water-insoluble glucan formation }\end{array}$ & In vitro & {$[105]$} \\
\hline $\begin{array}{l}\text { Brazil (extracts of propolis from the states of } \\
\text { Minas Gerais and Rio Grande do Sul) }\end{array}$ & Cariostatic effect & Human & {$[106]$} \\
\hline Brazil (extract of propolis from Bahia state) & $\begin{array}{l}\text { Exceptionally effective against Streptococcus } \\
\text { mutans }\end{array}$ & In vitro & {$[107]$} \\
\hline Apigenin and tt-farnesol & Glucosyltransferase activity & In vivo-rats & [108] \\
\hline Apigenin and tt-farnesol (association) & Cariostatic effect & In vitro & [109] \\
\hline Brazil (Isolated fractions) & Cariostatic effect & $\begin{array}{l}\text { In vitro and in } \\
\text { vivo }\end{array}$ & {$[110]$} \\
\hline Brazil (Bahia state) & Cariostatic effect & In vivo-rats & {$[111]$} \\
\hline Brazil (extracts of propolis) & Cariostatic effect & Human & {$[112]$} \\
\hline Tunisia & $\begin{array}{l}\text { Cariogenic activity } \\
\text { Inhibition oral biofilm formation }\end{array}$ & In vitro & [93] \\
\hline Korea & Antibacterial activity & In vitro & [113] \\
\hline
\end{tabular}


to have direct antimicrobial effects in vitro [48]. Some recent studies suggested that propolis can be used in medicine and dentistry. Tables 7 and 8 illustrate some studies that show the application of propolis in medicine and dentistry.

\section{Conclusions}

Propolis has been used extensively as a folk medicine because of its special chemical components, strong pharmacological, properties and low toxicity. This wide spectrum of therapeutic effects makes propolis a potential candidate in several clinical scenarios. Clinical studies are now also in progress to verify the effects of propolis in the prevention and treatment of diseases.

The application of propolis is mostly in the drug or food manufacture in the form of mixtures. Current opinion is that the use of standardized preparations of propolis is safe and less toxic than many synthetic medicines, but the components of propolis are variable, and it is difficult to standardize and apply propolis. Robust manufacturing processes, standardized quality controls, and good design clinical trials are all critical steps in verifying these claims.

\section{References}

[1] W. Greenaway, T. Scaysbrook, and F. R. Whately, “The composition and plant origin of propolis: a report of work Oxford," Bee World, vol. 71, no. 3, pp. 107-118, 1990.

[2] E. L. Ghisalberti, "Propolis: a review," Bee World, vol. 60, no. 2, pp. 59-84, 1979.

[3] T. Matsuno, Y. Matsumoto, M. Saito, and J. Morikawa, "Isolation and characterization of cytotoxic diterpenoid isomers from propolis," Zeitschrift für Naturforschung C, vol. 52, no. 9-10, pp. 702-704, 1997.

[4] N. Vynograd, I. Vynograd, and Z. Sosnowski, "A comparative multi-centre study of the efficacy of propolis, acyclovir and placebo in the treatment of genital herpes (HSV)," Phytomedicine, vol. 7, no. 1, pp. 1-6, 2000.

[5] T. Kimoto, M. Aga, K. Hino et al., "Apoptosis of human leukemia cells induced by Artepillin C, an active ingredient of Brazilian propolis," Anticancer Research, vol. 21, no. 1 A, pp. 221-228, 2001.

[6] T. Kimoto, S. Arai, M. Kohguchi et al., "Apoptosis and suppression of tumor growth by Artepillin C extracted from Brazilian propolis," Cancer Detection and Prevention, vol. 22, no. 6, pp. 506-515, 1998.

[7] P. Basnet, T. Matsuno, and R. Neidlein, "Potent free radical scavenging activity of propol isolated from Brazilian propolis," Zeitschrift für Naturforschung C, vol. 52, no. 11-12, pp. 828-833, 1997.

[8] Y. K. Park, M. H. Koo, J. A. S. Abreu, M. Ikegaki, J. A. Cury, and P. L. Rosalen, "Antimicrobial activity of propolis on oral microorganisms," Current Microbiology, vol. 36, no. 1, pp. 2428, 1998.

[9] J. Ito, F. R. Chang, H. K. Wang et al., "Anti-AIDS agents. 48. Anti-HIV activity of moronic acid derivatives and the new melliferone-related triterpenoid isolated from Brazilian propolis," Journal of Natural Products, vol. 64, no. 10, pp. 1278-1281, 2001.

[10] G. A. Burdock, "Review of the biological properties and toxicity of bee propolis (propolis)," Food and Chemical Toxicology, vol. 36, no. 4 , pp. 347-363, 1998.
[11] V. Bankova and N. Marekov, "Propolis-chemical composition and standardization," Farmatsiya, vol. 32, pp. 8-18, 1984.

[12] C. Garcia-Vigueira, W. Greenaway, and F. Whatley, "Composition of propolis from two different Spanish regions," Zeitschrift für Naturforschung C, vol. 47, pp. 634-637, 1992.

[13] B. Konig, "Plant sources of propolis," Bee World, vol. 66, no. 4, pp. 136-139, 1985.

[14] Y. K. Park, S. M. Alencar, and C. L. Aguiar, "Botanical origin and chemical composition of Brazilian propolis," Journal of Agricultural and Food Chemistry, vol. 50, no. 9, pp. 2502-2506, 2002.

[15] Y. K. Park, J. F. Paredes-Guzman, C. L. Aguiar, S. M. Alencar, and F. Y. Fujiwara, "Chemical constituents in Baccharis dracunculifolia as the main botanical origin of Southeastern Brazilian propolis," Journal of Agricultural and Food Chemistry, vol. 52, no. 5, pp. 1100-1103, 2004.

[16] M. C. Marcucci, "Propolis: chemical composition, biological properties and therapeutic activity," Apidologie, vol. 26, no. 2, pp. 83-99, 1995.

[17] A. Daugsch, C. S. Moraes, P. Fort, and Y. K. Park, "Brazilian red propolis-chemical composition and botanical origin," Evidence-Based Complementary and Alternative Medicine, vol. 5, no. 4, pp. 435-441, 2008.

[18] S. Castaldo and F. Capasso, "Propolis, an old remedy used in modern medicine," Fitoterapia, vol. 73, supplement 1, pp. S1-S6, 2002.

[19] E. Crane, “The past and present importance of bee products to man," in Bee Products-Properties, Applications, and Apitherapy, A. Mizrahi and Y. Lensky, Eds., pp. 1-13, Plenum Press, New York, NY, USA, 1997.

[20] A. S. Pereira, F. R. M. S. Seixas, and F. R. Aquino Neto, "Própolis: 100 anos de pesquisa e suas perspectivas futuras," Química Nova, vol. 25, no. 2, pp. 321-326, 2002.

[21] D. Suárez, D. Zayas, and F. Guisado, "Propolis: patents and technology trends for health applications," Journal of Business Chemistry, vol. 2, no. 3, pp. 119-125, 2005.

[22] "Ministério do desenvolvimento da indústria e comércio," http://aliceweb.mdic.gov.br.

[23] H. Aga, T. Shibuya, T. Sugimoto, M. Kurimoto, and S. Nakajima, "Isolation and identification of antimicrobial compounds in Brazilian propolis," Bioscience, Biotechnology and Biochemistry, vol. 58, no. 5, pp. 945-946, 1994.

[24] W. Thomson, "Propolis," Medical Journal of Australia, vol. 153, article 654, 1990.

[25] K. R. Markham, K. A. Mitchell, A. L. Wilkins, J. A. Daldy, and Y. Lu, "HPLC and GC-MS identification of the major organic constituents in New Zealand propolis," Phytochemistry, vol. 42, no. 1, pp. 205-211, 1996.

[26] V. Bankova, G. Boudourova-Krasteva, J. M. Sforcin et al., "Phytochemical evidence for the plant origin of Brazilian propolis from Sao Paulo state," Zeitschrift für Naturforschung C, vol. 54, no. 5-6, pp. 401-405, 1999.

[27] A. Kujumgiev, I. Tsvetkova, Y. Serkedjieva, V. Bankova, R. Christov, and S. Popov, "Antibacterial, antifungal and antiviral activity of propolis of different geographic origin," Journal of Ethnopharmacology, vol. 64, no. 3, pp. 235-240, 1999.

[28] S. Kumazawa, T. Hamasaka, and T. Nakayama, "Antioxidant activity of propolis of various geographic origins," Food Chemistry, vol. 84, no. 3, pp. 329-339, 2004.

[29] H. Katircioğlu and N. Mercan, "Antimicrobial activity and chemical compositions of Turkish propolis from different regions," African Journal of Biotechnology, vol. 5, no. 11, pp. 11511153, 2006. 
[30] V. Bankova, G. Boudourova-Krasteva, S. Popov, J. M. Sforcin, and S. R. C. Funari, "Seasonal vatiations of the chemical composition of Brazilian propolis," Apidologie, vol. 29, no. 4, pp. 361-367, 1998.

[31] J. M. Sforcin, E. L. Novelli, and S. R. C. Funari, "Seasonal effect of Brazilian propolis on seric biochemical variables," Journal of Venomous Animals and Toxins Including Tropical Diseases, vol. 8, pp. 244-254, 2000.

[32] S. Silici and S. Kutluca, "Chemical composition and antibacterial activity of propolis collected by three different races of honeybees in the same region," Journal of Ethnopharmacology, vol. 99, no. 1, pp. 69-73, 2005.

[33] M. L. Castro, J. A. Cury, P. L. Rosalen et al., "Própolis do sudeste e nordeste do Brasil: influência da sazonalidade na atividade antibacteriana e composição fenólica," Química Nova, vol. 30, pp. 1512-1521, 2007.

[34] V. S. Bankova, S. L. de Castro, and M. C. Marcucci, "Propolis: recent advances in chemistry and plant origin," Apidologie, vol. 31, no. 1, pp. 3-15, 2000.

[35] Y. Xu, L. Luo, B. Chen, and Y. Fu, "Recent development of chemical components in propolis," Frontiers of Biology in China, vol. 4, no. 4, pp. 385-391, 2009.

[36] J. O. Schmidt, "Chemical composition and application," in Bee Products-Properties, Applications, and Apitherapy, A. Mizrahi and Y. Lensky, Eds., pp. 15-26, New York, New York, NY, USA, 1997.

[37] E. Crane, Beekeping: Science, Practice and World Resources, Butterworth Heinemann, London, UK, 1988.

[38] V. Bankova, "Chemical diversity of propolis and the problem of standardization," Journal of Ethnopharmacology, vol. 100, no. 12, pp. 114-117, 2005.

[39] R. Christov, B. Trusheva, M. Popova, V. Bankova, and M. Bertrand, "Chemical composition of propolis from Canada, its antiradical activity and plant origin," Natural Product Research, vol. 19, no. 7, pp. 673-678, 2005.

[40] B. Trusheva, M. Popova, V. Bankova et al., "Bioactive constituents of Brazilian red propolis," Evidence-Based Complementary and Alternative Medicine, vol. 3, no. 2, pp. 249-254, 2006.

[41] Y. K. Park, M. Ikegaki, S. M. Alencar, and F. F. Moura, "Evaluation of Brazilian propolis by both physicochemical methods and biological activity," Honeybee Science, vol. 21, no. 2, pp. 8590, 2000.

[42] S. M. Alencar, T. L. C. Oldoni, M. L. Castro et al., "Chemical composition and biological activity of a new type of Brazilian propolis: red propolis," Journal of Ethnopharmacology, vol. 113, no. 2, pp. 278-283, 2007.

[43] J. F. M. da Silva, M. C. de Souza, S. R. Matta, M. R. de Andrade, and F. V. N. Vidal, "Correlation analysis between phenolic levels of Brazilian propolis extracts and their antimicrobial and antioxidant activities," Food Chemistry, vol. 99, no. 3, pp. 431435, 2006.

[44] K. Salomão, P. R. S. Pereira, L. C. Campos et al., "Brazilian propolis: correlation between chemical composition and antimicrobial activity," Evidence-Based Complementary and Alternative Medicine, vol. 5, no. 3, pp. 317-324, 2008.

[45] I. S. R. Cabral, T. L. C. Oldoni, A. Prado, R. M. N. Bezerra, and S. M. Alencar, "Composição fenólica, atividade antibacteriana e antioxidante da própolis vermelha brasileira," Química Nova, vol. 32, no. 6, pp. 1523-1527, 2009.

[46] E. Gregoris and R. Stevanato, "Correlations between polyphenolic composition and antioxidant activity of Venetian propolis," Food and Chemical Toxicology, vol. 48, no. 1, pp. 76-82, 2010.
[47] A. A. Righi, T. R. Alves, G. Negri, L. M. Marques, H. Breyer, and A. Salatino, "Brazilian red propolis: unreported substances, antioxidant and antimicrobial activities," Journal of the Science of Food and Agriculture, vol. 91, pp. 2363-2370, 2011.

[48] A. Ugur and T. Arslan, "An in vitro study on antimicrobial activity of propolis from Mugla Province of Turkey," Journal of Medicinal Food, vol. 7, no. 1, pp. 90-94, 2004.

[49] L. C. Paviani, C. Dariva, M. C. Marcucci, and F. A. Cabral, "Supercritical carbon dioxide selectivity to fractionate phenolic compounds from the dry ethanolic extract of propolis," Journal of Food Process Engineering, vol. 33, no. 1, pp. 15-27, 2010.

[50] V. S. Bankova, S. S. Popov, and N. L. Marekov, "A study on flavonoids of propolis," Journal of Natural Products, vol. 46, no. 4, pp. 471-474, 1983.

[51] V. Bankova, A. Dyulgerov, S. Popov, and N. Marekov, "A GC/MS study of the propolis phenolic constituents," Zeitschrift für Naturforschung C, vol. 42, pp. 147-151, 1987.

[52] G. Boudourova-Krasteva, V. Bankova, J. M. Sforcin, N. Nikolova, and S. Popov, "Phenolics from Brazilian propolis," Zeitschrift für Naturforschung C, vol. 52, no. 9-10, pp. 676-679, 1997.

[53] M. C. Marcucci, J. Rodriguez, F. Ferreres, and V. Bankova, "Chemical composition of Brazilian propolis from Sao Paulo state," Zeitschrift für Naturforschung C, vol. 53, no. 1-2, pp. 117$119,1998$.

[54] S. Tazawa, T. Warashina, and T. Noro, "Studies on the constituents of Brazilian propolis. II," Chemical and Pharmaceutical Bulletin, vol. 47, no. 10, pp. 1388-1392, 1999.

[55] S. Kumazawa, R. Ueda, T. Hamasaka, S. Fukumoto, T. Fujimoto, and T. Nakayama, "Antioxidant prenylated flavonoids from propolis collected in Okinawa, Japan," Journal of Agricultural and Food Chemistry, vol. 55, no. 19, pp. 7722-7725, 2007.

[56] M. L. Castro, A. M. D. Nascimento, M. Ikegaki, C. M. CostaNeto, S. M. Alencar, and P. L. Rosalen, "Identification of a bioactive compound isolated from Brazilian propolis type 6," Bioorganic and Medicinal Chemistry, vol. 17, no. 14, pp. 53325335, 2009.

[57] C. Lotti, M. C. Fernandez, A. L. Piccinelli, O. Cuesta-Rubio, I. M. Hernández, and L. Rastrelli, "Chemical constituents of red Mexican propolis," Journal of Agricultural and Food Chemistry, vol. 58, no. 4, pp. 2209-2213, 2010.

[58] M. P. Popova, K. Graikou, I. Chinou, and V. S. Bankova, "GCMS profiling of diterpene compounds in Mediterranean propolis from Greece," Journal of Agricultural and Food Chemistry, vol. 58, no. 5, pp. 3167-3176, 2010.

[59] A. Petrova, M. Popova, C. Kuzmanova et al., "New biologically active compounds from Kenyan propolis," Fitoterapia, vol. 81, no. 6, pp. 509-514, 2010.

[60] B. Trusheva, M. Popova, E. B. Koendhori, I. Tsvetkova, C. Naydenski, and V. Bankova, "Indonesian propolis: chemical composition, biological activity and botanical origin," Natural Product Research, vol. 25, no. 6, pp. 606-613, 2011.

[61] S. A. Shaheen, M. H. Zarga, I. K. Nazer, R. M. Darwish, and H. I. Al-Jaber, "Chemical constituents of Jordanian propolis," Natural Product Research, vol. 25, no. 14, pp. 1312-1318, 2011.

[62] C. Lotti, A. L. Piccineli, C. Arevalo et al., "Constituents of Hondurian propolis with inhibitory effects on Saccharomyces cerevisiae multidrug resistance protein Pdr5p," Journal of Agricultural and Food Chemistry, vol. 60, no. 42, pp. 10540-10545, 2012.

[63] V. Bankova, R. Christov, S. Popov, O. Pureb, and G. Bocari, "Volatile constituents of propolis," Zeitschrift für Naturforschung C, vol. 49, pp. 6-10, 1994. 
[64] V. Bankova, R. Christov, A. Kujumgiev, M. C. Marcucci, and S. Popov, "Chemical composition and antibacterial activity of Brazilian propolis," Zeitschrift für Naturforschung C, vol. 50, no. 3-4, pp. 167-172, 1995.

[65] E. Nagy, V. Papay, G. Litkei, and Z. Dinya, "Investigation of the chemical constituents, particularly the flavonoid components, of propolis and Populi gemma by GC/MS method," Studies in Organic Chemistry, vol. 23, pp. 223-232, 1986.

[66] S. A. Popravko and M. V. Sokolov, "Plant sources of propolis," Pchelovodstvo, vol. 2, pp. 28-29, 1980 (Russian).

[67] M. C. Marcucci and V. S. Bankova, "Chemical composition, plant origin and biological activity of Brazilian propolis," Current Topics in Phytochemistry, vol. 2, pp. 115-123, 1999.

[68] F. A. Tomás-Barberán, C. García-Vigueira, P. Vit-Olivier, F. Ferreres, and F. Tomás-Lorente, "Phytochemical evidence for the botanical origin $\mathrm{f}$ tropical propolis from Venezuela," Phytochemistry, vol. 34, no. 1, pp. 191-196, 1993.

[69] O. Cuesta-Rubio, B. A. Frontana-Uribe, T. Ramírez-Apan, and J. Cárdenas, "Polyisoprenylated benzophenones in Cuban propolis; biological activity of nemorosone," Zeitschrift für Naturforschung C, vol. 57, no. 3-4, pp. 372-378, 2002.

[70] B. Trusheva, M. Popova, H. Naydenski, I. Tsvetkova, J. G. Rodriguez, and V. Bankova, "New polyisoprenylated benzophenones from Venezuelan propolis," Fitoterapia, vol. 75, no. 7-8, pp. 683-689, 2004.

[71] Y. K. Park, S. M. Alencar, A. R. P. Scamparini, and C. L. Aguiar, "Própolis produzida no Sul do Brasil, Argentina e Uruguai: evidências fitoquímicas de sua origem vegetal," Ciência Rural, vol. 32, no. 6, pp. 997-1003, 2002.

[72] A. H. Banskota, Y. Tezuka, I. K. Adnyana et al., "Hepatoprotective and anti-Helicobacter pylori activities of constituents from Brazilian propolis," Phytomedicine, vol. 8, no. 1, pp. 16-23, 2001.

[73] T. Matsuno, Y. Matsumoto, M. Saito, and J. Mprikawa, "Antitumor benzopyran derivative of propolis," Chemical Abstracts, vol. 126, Article ID 39814j, 1997.

[74] T. Matsuno, M. Saito, Y. Matsumoto, and J. Morikawa, "A new benzo- $\gamma$-pyran derivative isolated from propolis," Zeitschrift für Naturforschung C, vol. 53, no. 11-12, pp. 1037-1039, 1998.

[75] T. Hashimoto, H. Aga, A. Tabuchi et al., "Anti-Helicobacter pylori compounds in Brazilian propolis," Natural Medicines, vol. 52, no. 6, pp. 518-520, 1998.

[76] D. Grunberger, R. Banerjee, K. Eisinger et al., "Preferential cytotoxicity on tumor cells by caffeic acid phenethyl ester isolated from propolis," Experientia, vol. 44, no. 3, pp. 230-232, 1988.

[77] O. K. Mirzoeva and P. C. Calder, "The effect of propolis and its components on eicosanoid production during the inflammatory response," Prostaglandins Leukotrienes and Essential Fatty Acids, vol. 55, no. 6, pp. 441-449, 1996.

[78] B. Konig and J. H. Dustmann, "Fortschritte der celler untersuchungen zur antivirotischen aktivität von propolis," Apidologie, vol. 15, pp. 228-230, 1985.

[79] V. R. Villanueva, M. Barbier, M. Gonnet, and P. Lavie, “The flavonoids of propolis. Isolation of a new bacteriostatic substance: pinocembrin (dihydroxy-5, 7 flavanone)," Annales de l'Institut Pasteur, vol. 118, no. 1, pp. 84-87, 1970.

[80] J. Metzner, E. M. Schneidewind, and E. Friedrich, "On the effects of propolis and pinocembrin on blastomyces," Pharmazie, vol. 32, no. 11, p. 730, 1977.

[81] P. Basnet, K. Matsushige, K. Hase, S. Kadota, and T. Namba, "Four di-O-caffeoyl quinic acid derivatives from propolis. Potent hepatoprotective activity in experimental liver injury models," Biological and Pharmaceutical Bulletin, vol. 19, no. 11, pp. 1479-1484, 1996.

[82] M. Paintz and J. Metzner, "Zur iokalanästhetischen wirkung von propolis und einigen Inhaltsstoffen," Pharmazie, vol. 34, pp. 839-841, 1979.

[83] M. Miyakado, T. Kato, N. Ohno, and T. J. Mabry, "Pinocembrin and (+)- $\beta$-eudesmol from Hymenoclea monogyra and Baccharis glutinosa," Phytochemistry, vol. 15, no. 5, p. 846, 1976.

[84] K. Hayashi, S. Komura, N. Isaji, N. Ohishi, and K. Yagi, "Isolation of antioxidative compounds from Brazilian propolis: 3,4dihydroxy-5-prenylcinnamic acid, a novel potent antioxidant," Chemical and Pharmaceutical Bulletin, vol. 47, no. 11, pp. 15211524, 1999.

[85] T. Kimoto, S. Koya-Miyata, K. Hino et al., "Pulmonary carcinogenesis induced by ferric nitrilotriacetate in mice and protection from it by Brazilian propolis and artepillin C," Virchows Archiv, vol. 438, no. 3, pp. 259-270, 2001.

[86] Y. Akao, H. Maruyama, K. Matsumoto et al., "Cell growth inhibitory effect of cinnamic acid derivatives from propolis on human tumor cell lines," Biological and Pharmaceutical Bulletin, vol. 26, no. 7, pp. 1057-1059, 2003.

[87] Y. K. Park, I. Fukuda, H. Ashida et al., "Suppression of dioxin mediated aryl hydrocarbon receptor transformation by ethanolic extracts of propolis," Bioscience, Biotechnology and Biochemistry, vol. 68, no. 4, pp. 935-938, 2004.

[88] A. Russo, V. Cardile, F. Sanchez, N. Troncoso, A. Vanella, and J. A. Garbarino, "Chilean propolis: antioxidant activity and antiproliferative action in human tumor cell lines," Life Sciences, vol. 76, no. 5, pp. 545-558, 2004.

[89] Y. Inokuchi, M. Shimazawa, Y. Nakajima, S. Suemori, S. Mishima, and H. Hara, "Brazilian green propolis protects against retinal damage in vitro and in vivo," Evidence-Based Complementary and Alternative Medicine, vol. 3, no. 1, pp. 7177, 2006.

[90] H. Li, A. Kapur, J. X. Yang et al., "Antiproliferation of human prostate cancer cells by ethanolic extracts of Brazilian propolis and its botanical origin," International Journal of Oncology, vol. 31, no. 3, pp. 601-606, 2007.

[91] T. Shimizu, A. Hino, A. Tsutsumi, K. P. Yong, W. Watanabe, and M. Kurokawa, "Anti-influenza virus activity of propolis in vitro and its efficacy against influenza infection in mice," Antiviral Chemistry and Chemotherapy, vol. 19, no. 1, pp. 7-13, 2008.

[92] R. M. Darwish, R. J. A. Fares, M. H. A. Zarga, and I. K. Nazer, "Antibacterial effect of Jordanian propolis and isolated flavonoids against human pathogenic bacteria," African Journal of Biotechnology, vol. 9, no. 36, pp. 5966-5974, 2010.

[93] B. Kouidhi, T. Zmantar, and A. Bakhrouf, "Anti-cariogenic and anti-biofilms activity of Tunisian propolis extract and its potential protective effect against cancer cells proliferation," Anaerobe, vol. 16, no. 6, pp. 566-571, 2010.

[94] K. W. Cheung, D. M. Y. Sze, W. K. Chan, R. X. Deng, W. Tu, and G. C. F. Chan, "Brazilian green propolis and its constituent, artepellin $\mathrm{C}$ inhibits allogenic activated human CD4 $\mathrm{T}$ cells expansion and activation," Journal of Ethnopharmacology, vol. 138, no. 2, pp. 463-471, 2011.

[95] M. J. Valente, A. F. Baltazar, R. Henrique, L. Estevinho, and M. Carvalho, "Biological activities of Portuguese propolis: protection against free radical-induced erythrocyte damage and inhibition of human renal cancer cell growth in vitro," Food and Chemical Toxicology, vol. 49, no. 1, pp. 86-92, 2011.

[96] J. Shvarzbeyn and M. Huleihel, "Effect of propolis and caffeic acid phenethyl ester (CAPE) on NF $\kappa$ B activation by HTLV-1 Tax," Antiviral Research, vol. 90, no. 3, pp. 108-115, 2011. 
[97] T. Kamiya, H. Nishihara, H. Hara, and T. Adachi, "Ethanol extract of Brazilian red propolis induces apoptosis in human breast cancer MCF-3 cells through endoplasmic reticulum stress," Journal of Agricultural and Food Chemistry, vol. 60, no. 44, pp. 11065-11070, 2012.

[98] G. C. Franchi Jr., C. S. Moraes, V. C. Toreti, A. Daugsch, A. E. Nowill, and Y. K. Park, "Comparison of effects of the ethanolic extracts of Brazilian propolis on human leukemic cells as assessed with the MTT assay," Evidence-Based Complementary and Alternative Medicine, vol. 2012, Article ID 918956, 6 pages, 2012.

[99] C. P. Chuu, H. P. Lin, M. F. Ciacco et al., "Caffeic acid phenethyl ester suppresses the proliferation on human prostate cancer cells through inhibition of p70S6K and Akt signaling networks," Cancer Prevention Research, vol. 5, no. 5, pp. 788-797, 2012.

[100] K. Yasukawa, S. Y. Yu, S. Tsutsumi, M. Kurokawa, and Y. K. Park, "Inhibitory effects of Brazilian propolis on tumor promotion in two-stage mouse skin carcinogenesis," Journal of Pharmacy and Nutrition Sciences, vol. 2, pp. 71-76, 2012.

[101] R. Zukowska-Markiewicz, M. H. Borawska, A. Fiedorowicz, S. K. Naliwajko, D. Sawicka, and H. Car, "Propolis changes the anticancer activity of temozolomide in U87MG human glioblastoma cell line," Evidence-Based Complementary and Alternative Medicine, vol. 13, article 50, 2013.

[102] K. Ikeno, T. Ikeno, and C. Miyazawa, "Effects of propolis on dental caries in rats," Caries Research, vol. 25, no. 5, pp. 347-351, 1991.

[103] H. Koo, P. L. Rosalen, J. A. Cury, Y. K. Park, M. Ikegaki, and A. Sattler, "Effect of Apis mellifera propolis from two Brazilian regions on caries development in desalivated rats," Caries Research, vol. 33, no. 5, pp. 393-400, 1999.

[104] H. Koo, A. M. Vacca Smith, W. H. Bowen, P. L. Rosalen, J. A. Cury, and Y. K. Park, "Effects of Apis mellifera propolis on the activities of streptococcal glucosyltransferases in solution and adsorbed onto saliva-coated hydroxyapatite," Caries Research, vol. 34, no. 5, pp. 418-426, 2000.

[105] H. Koo, B. P. F. A. Gomes, P. L. Rosalen, G. M. B. Ambrosano, Y. K. Park, and J. A. Cury, "In vitro antimicrobial activity of propolis and Arnica montana against oral pathogens," Archives of Oral Biology, vol. 45, no. 2, pp. 141-148, 2000.

[106] H. Koo, J. A. Cury, P. L. Rosalen, G. M. B. Ambrosano, M. Ikegaki, and Y. K. Park, "Effect of a mouthrinse containing selected propolis on 3-day dental plaque accumulation and polysaccharide formation," Caries Research, vol. 36, no. 6, pp. 445-448, 2002.

[107] H. Koo, P. L. Rosalen, J. A. Cury et al., "Effect of a new variety of Apis mellifera propolis on mutans streptococci," Current Microbiology, vol. 41, no. 3, pp. 192-196, 2000.

[108] H. Koo, S. K. Pearson, K. Scott-Anne et al., "Effects of apigenin and $\mathrm{tt}$-farnesol on glucosyltransferase activity, biofilm viability and caries development in rats," Oral Microbiology and Immunology, vol. 17, no. 6, pp. 337-343, 2002.

[109] H. Koo, B. Schobel, K. Scott-Anne et al., "Apigenin and $t t-$ farnesol with fluoride effects on S. mutans biofilms and dental caries," Journal of Dental Research, vol. 84, no. 11, pp. 1016-1020, 2005.

[110] M. F. Hayacibara, H. Koo, P. L. Rosalen et al., "In vitro and in vivo effects of isolated fractions of Brazilian propolis on caries development," Journal of Ethnopharmacology, vol. 101, no. 1-3, pp. 110-115, 2005.

[111] S. Duarte, P. L. Rosalen, M. F. Hayacibara et al., "The influence of a novel propolis on mutans streptococci biofilms and caries development in rats," Archives of Oral Biology, vol. 51, no. 1, pp. $15-22,2006$.

[112] S. A. D. C. Duailibe, A. G. Gonçalves, and F. J. M. Ahid, "Effect of a propolis extract on Streptococcus mutans counts in vivo," Journal of Applied Oral Science, vol. 15, no. 5, pp. 420-423, 2007.

[113] M. J. Kini, C. S. Kini, B. H. Kim et al., "Antimicrobial effect of Korean propolis against the mutans streptococci isolated from Korean," Journal of Microbiology, vol. 49, no. 1, pp. 161-164, 2011. 


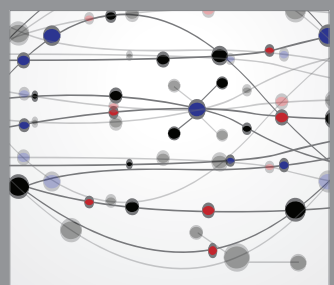

The Scientific World Journal
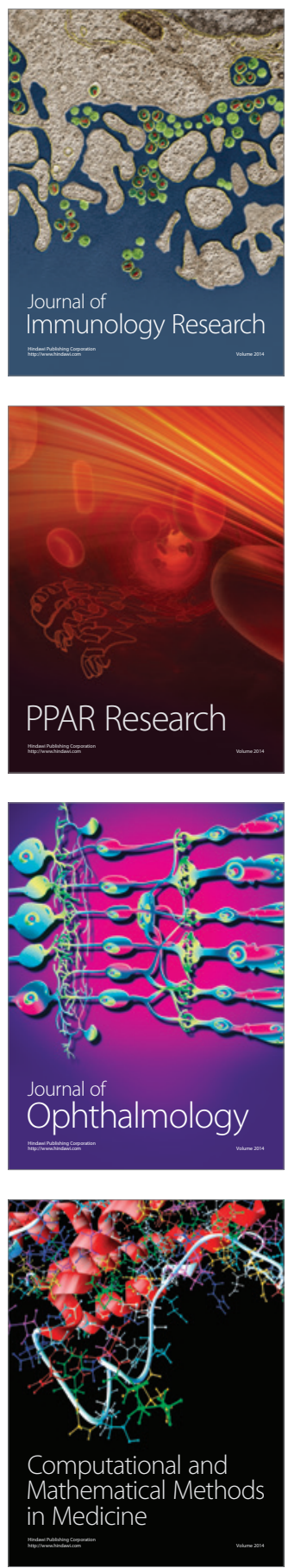

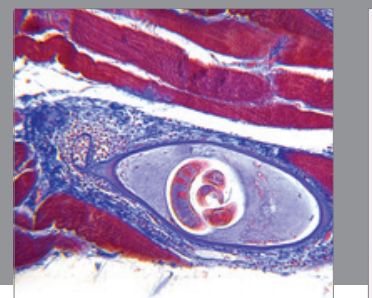

Gastroenterology

Research and Practice
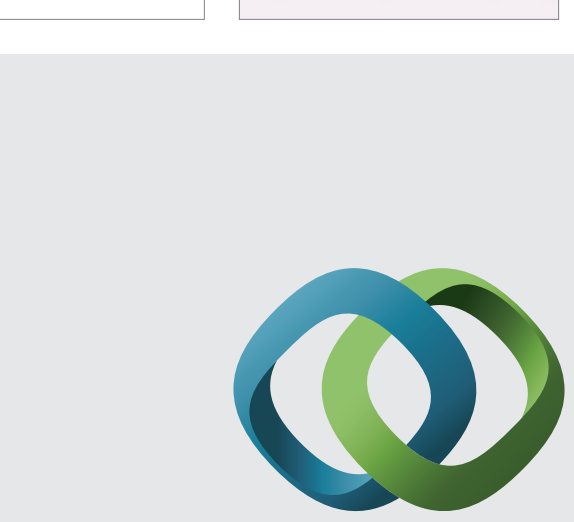

\section{Hindawi}

Submit your manuscripts at

http://www.hindawi.com
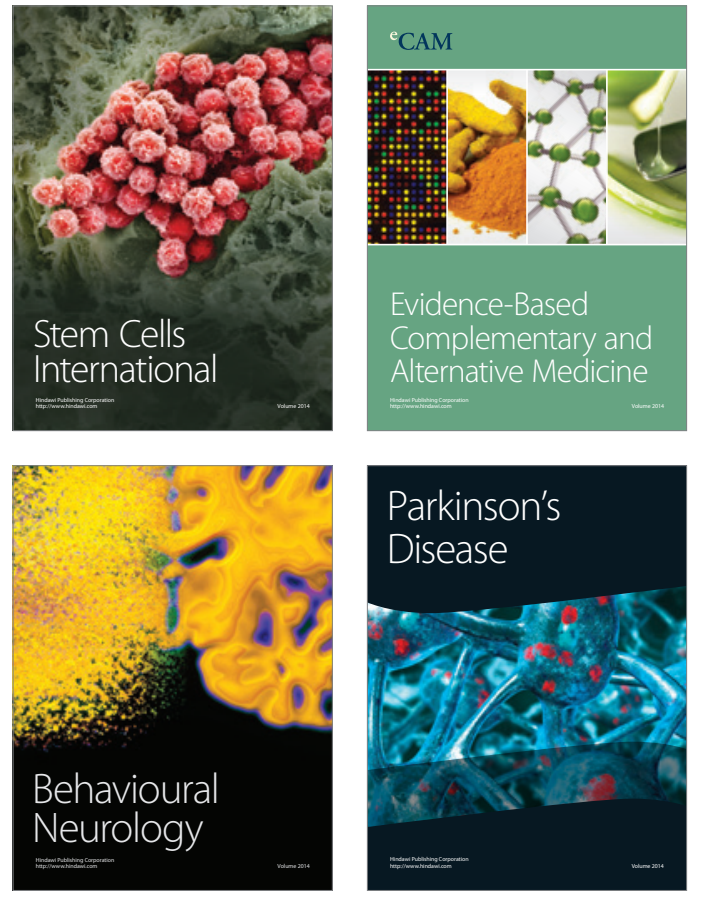
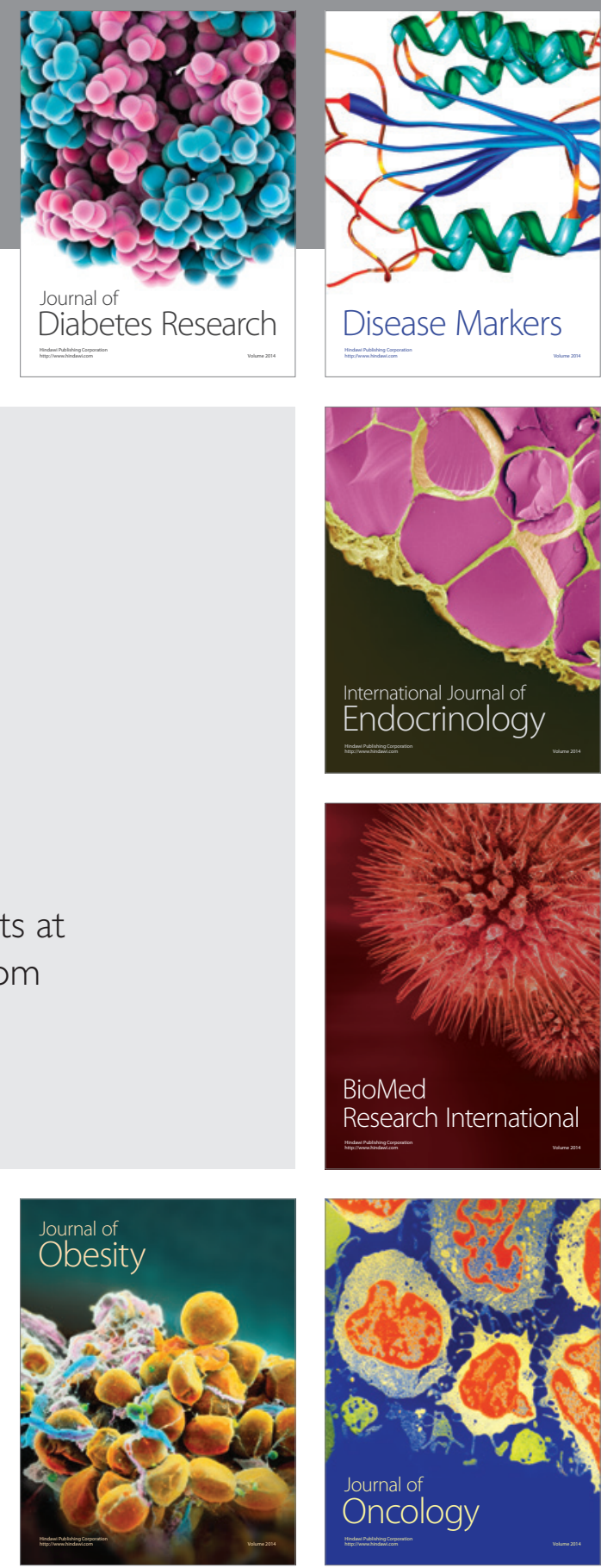

Disease Markers
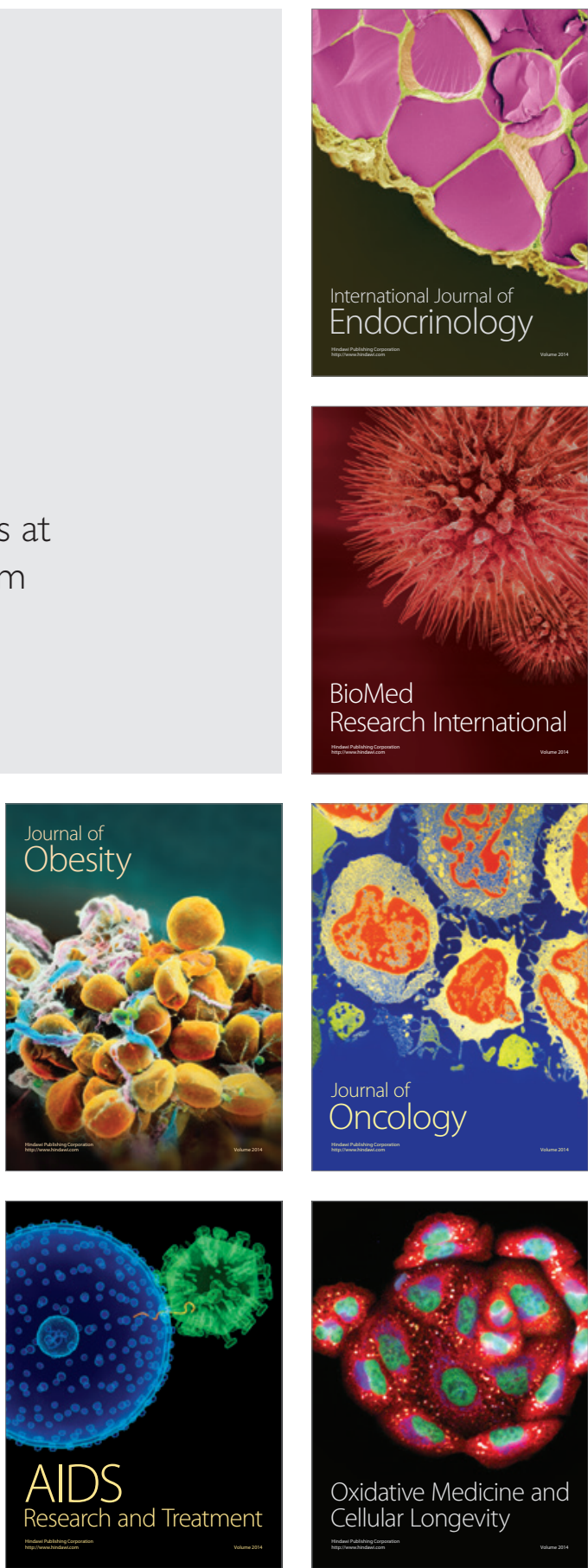